\author{
Labeckas G., Slavinskas S., Mackevičius T. \\ Vytautas Magnus university, Kaunas-Academy, Lithuania
}

\title{
PERFORMANCE AND EMISSIONS OF A DIESEL ENGINE OPERATING WITH RENEWABLE BINARY BIODIESEL-N-BUTANOL BIOFUEL BLENDS
}

This paper presents a comparative analysis of the diesel engine performance and emission characteristics, when operating on rapeseed methyl ester (B) and rapeseed methyl ester -butanol (Bu5, Bu10, Bu15) blends, at various loads and $2000 \mathrm{rpm}$ engine speeds. The experimental tests were performed on a four-stroke, single-cylinder, air-cooled diesel engine FL511. The bench test results showed that the brake specific fuel consumption increased, when operating on biodiesel-butanol fuel blends compared to neat biodiesel. The maximum brake thermal efficiency sustained at the levels from $7.3 \%$ to $12.9 \%$ lower in comparison with neat biodiesel operating at low engine load. When the engine was running at maximum torque mode using biodiesel-butanol fuel blend Bu15 the total emissions of nitrogen oxides decreased. Thus, the greatest fossil fuel challenge related with the simultaneous reduction of both the NOx emissions and the smoke opacity (PM) could be reasonably solved by switching a diesel engine on totally renewable biodiesel-n-butanol biofuel blends.

Keywords: diesel engine, rapeseed oil derived biodiesel, n-butanol, engine efficiency, brake specific fuel consumption, emissions, smoke opacity.

\section{INTRODUCTION}

The Directive 2009/28/EC of the European Parliament and the Council on the promotion of the use of energy from renewable sources [1] approved a target of a $20 \%$ of European energy consumption using renewable fuels in a cost-effective way. This Directive fixes at $10 \%$ the minimum consumption of renewable fuel used in transport-sector by 2020 and creates a challenge for both the scientists and the industry. Keeping in a track with the newest trends to use lighter and more environment friendly biofuels for a diesel engine powering, Giakoumis et al. [2], Rakopoulos et al. [3], Labeckas et al. [4] tested n-butanol in diesel fuel blends. The research revealed [4], due to the longer auto-ignition delay period of a pilot portion of diesel-nbutanol fuel blends both the fuel-energy conversion efficiency representing burn angle MBF 50, at which burns a half of the injected fuel portion, and the end of combustion occur earlier in an engine cycle after TDC. In result, the brake thermal efficiency increases to maximum value of 0.383 when running with diesel fuel blend involving n-butanol DB3 (3.0 wt\% oxygen) at speed of $1800 \mathrm{rpm}$. While the $\mathrm{NO}_{\mathrm{x}}, \mathrm{CO}$ and THC emissions decrease by $5.1 \%, 29.5 \%$ and 3,7 times, respectively, when running with the most n-butanol involving blend DB4 (4.0 wt\% oxygen) against analogous values a fully loaded straight diesel produces at a higher speed of $2500 \mathrm{rpm}$. The scientists Sukjit et al. [5] progressed further with totally renewable and environment friendly binary, biodiesel-n-butanol biofuels adding to the intake manifold hydrogen to enhance combustion and drastically reduce $\mathrm{CO}$ and particulate matter (PM) emissions in compression ignition engines.

Normal butanol $\left(\mathrm{CH}_{3} \mathrm{CH}_{2} \mathrm{CH}_{2} \mathrm{CH}_{2} \mathrm{OH}\right)$ with molecular weight of $74.12 \mathrm{~g} / \mathrm{mol}$. is an alcoholic-origin colourless liquid of medium volatility and a characteristic banana-like odour. It is flammable enough with a flash point of around $35^{\circ} \mathrm{C}$, contains $21.62 \mathrm{wt} . \%$ of fuel-bound oxygen with a boiling point of about 117.40 ${ }^{\circ} \mathrm{C}$ at $760 \mathrm{~mm} \mathrm{Hg}$. This renewable biofuel added to widely known rapeseed oil methyl ester (RME) reduces density, viscosity, $\mathrm{C} / \mathrm{H}$ atoms ratio and provides plenty of fuel-bound oxygen that along with its good evaporative properties improves both the air and fuel vapours mixing rate and the combustion of biofuel blends. Because biodiesel and n-butanol contain a lower number than traditional diesel fuel the carbon atoms in the molecules, the enhanced combustion takes the advantage to reduce the total amount of both $\mathrm{CO}_{2}$ and $\mathrm{CO}$ emissions below the respective values of neat biodiesel or from a straight diesel could be expected. When being used as a oxygenator source in the above tests, anhydrous, 200 proof, ethanol $\left(\mathrm{CH}_{3} \mathrm{CH}_{2} \mathrm{OH}-\right.$ $99.9 \mathrm{vol} \%$ ) created more concern to the researchers than n-butanol in terms of the blends consistency, autoignition delay extension and combustion peculiarities. However, the presence of a lighter n-butanol in biodiesel also reduces the blended cetane number rating, net heating value and thus affects mass of biofuel consumed per unit of energy or effective power developed by an engine. A sensitive interaction between advantageous and disadvantageous operational properties of renewables with a widely differing nature, origin and production technology of biodiesel and n-butanol may lead to ambiguous development trends in the combustion attributes, net heat release rate and engine out emissions [4].

Wei et al. [6] investigated and compared biodiesel-ethanol (BE) and biodiesel-n-butanol (BBu) blendsmade effects on combustion, performance and emissions of a direct-injection diesel engine. Experiments 
were conducted on a straight diesel, biodiesel and BE5 (5\% ethanol and 95\% biodiesel, v/v), BE10, BE15 and $\mathrm{BBu} 5, \mathrm{BBu} 10, \mathrm{BBu} 15$ biofuel blends, at five engine loads and constant speed of $1800 \mathrm{rpm}$. The blended fuels lead to higher maximum heat release rate, higher maximum in-cylinder pressure, longer auto-ignition delay, and shorter combustion duration that all in a company evoked adverse effect on combustion noise and stability particularly when running with the BE blends. Moreover, on average of the five engine loads, the $\mathrm{BBu}$ and $\mathrm{BE}$ blends increased $\mathrm{CO}$ emission by $13.7 \%$ and $22.8 \%$ and $\mathrm{HC}$ emission by $5.6 \%$ and $29.2 \%$, respectively; but reduced $\mathrm{NO}_{\mathrm{x}}$ emission by $6.5 \%$ and $28.0 \%$, particle mass concentration by $20.7 \%$ and $20.6 \%$ and particle number concentration by $22 \%$ and $21 \%$, respectively. Thus the BE blends revealed themselves as being more effective in reducing particulate and $\mathrm{NO}_{\mathrm{x}}$ emissions, while the $\mathrm{BBu}$ blends suggested less increase in $\mathrm{CO}$ and $\mathrm{HC}$ emissions [6].

Zöldy [7] conducted a wide-range chemical-analytical investigation on properties of butanol, hydrogenated vegetable oil and diesel fuel blends and measured nearly 20 chemical and physical parameters, especially such as flash point, cetane number, viscosity and cold filter plugging point (CFPP) to find out whether or not the three component blends are suitable for compression ignition engines. The researcher estimated that the viscosity decreases within the test range nearly liner and every $1 \%$ of butanol mass content (v/v \%) added to the blend causes slight $1.4 \%$ decreasing effect on viscosity. He also noted that the added butanol decreases the blend's flash point to around $40{ }^{\circ} \mathrm{C}$ that is under the standard DIN EN ISO 2719, revised in 2016, minimum. This decrease is critical from the point of view of transportation fire-safety and logistics security. Because butanol-diesel and/or n-butanol-biodiesel fuel blends are flammable, the security equipment needs to be used as in the gasoline supply chain. Through wide-range experimental tests, the author disclosed that there about a liner relationship exists and the increase by $1 \%$ of butanol in Hydrotreated Vegetable Oil (HVO) content decreases the blended $\mathrm{CN}$ rating with an average of 0.4 points.

A lot of the research and development performed on n-butanol using in a diesel engine, however, there is not completely clear what could be the rational renewable biodiesel and n-butanol mixing rate that could be acceptable for diesel-powered machines and power generators. To make a difference, the undertaken research intends to put more light on the changing trends in performance parameters of a diesel engine, biofuels energy conversion efficiency and emissions of the exhaust when running alternately on neat biodiesel (B) derived from rapeseed oil as a 'baseline' fuel and a totally, renewable binary liquid biodiesel-nbutanol blends. Purpose of the research is to improve engine brake thermal efficiency, reduce $\mathrm{NO}_{\mathrm{x}}, \mathrm{CO}, \mathrm{CO}_{2}$ emissions and smoke opacity of the exhaust when running a single-cylinder, DI diesel engine on binary biodiesel-n-butanol blends under 5, 10, 15, 20, 25, 30 and $35 \mathrm{Nm}$ loads and maximum torque speed of 2000 $\mathrm{rpm}$. A four-stroke, air-cooled, naturally-aspirated diesel engine operated on a neat biodiesel (B) first, and then with the three totally renewable, binary biodiesel-n-butanol (BBu) blends BBu5 (95 vol.\% B/5 vol.\% $\mathrm{Bu}), \mathrm{BBu} 10(90 \mathrm{vol} . \% \mathrm{~B} / 10 \% \mathrm{Bu})$ and BBu15 (85vol.\% B/15vol.\% Bu) under the same loading conditions.

The test results of engine operation with various biodiesel-n-butanol blends are analysed and compared with the respective parameters measured when running with neat biodiesel derived from rapeseed oil at the respective loads, with particular attention to full (100\%) engine load, at constant speed of $2000 \mathrm{rpm}$. Because of the absence of polycyclic aromatic hydrocarbons in renewable biofuel blends, higher brake thermal efficiency, lower maximum $\mathrm{NO}_{\mathrm{x}}$ and drastically reduced $\mathrm{CO}$ emissions and smoke opacity (PM) could reasonably be expected due to potentially improved homogeneity of combustible mixture and particulate matter (PM) emissions benefits suggested by higher n-butanol-oxygen mass content $(21.62 \mathrm{wt} \%)$ and much lower carbon-to-hydrogen ratio (4.8).

\section{MATERIALS AND METHODS OF THE RESEARCH}

Regardless of both biodiesel (B) and n-butanol (Bu) are of the same renewable nature, nevertheless, the production of tested biofuels derives from different resources by using dissimilar technologies, therefore, these biofuels differ as having completely different origins with widely differing chemical and physical properties (Table 1). In contrast to ethanol [8], operational properties of n-butanol are much more similar to those of a straight diesel or biodiesel with the exception of lower density, viscosity and about twice as much lower $\mathrm{CN}$ rating the improvement of which rests on the higher cetane number of biodiesel. Moreover, $\mathrm{n}$ butanol provides operational advantages because its reasonable addition to biodiesel has the potential to drastically reduce the production of $\mathrm{CO}$ and smoke (PM) due to considerably lower $\mathrm{C} / \mathrm{H}$ atoms ratio and high fuel-bound oxygen mass (wt, \%) content. Next, the lower density and viscosity of n-butanol may have positive impact on biofuel injection, atomisation and vaporisation characteristics, the air and fuel vapours mixing rate in the hot in-cylinder compressed air charge, combustion attributes and thus engine out emissions when operating under steady and transient conditions [9]. 
Table 1. Properties of the tested rapeseed oil biodiesel and n-butanol

\begin{tabular}{|l|l|c|c|}
\hline \multicolumn{1}{|c|}{ Property parameters } & Fuel test methods & $\begin{array}{c}\text { Rapeseed } \\
\text { oil biodiesel } \\
(\mathrm{B})\end{array}$ & $\begin{array}{c}\text { N-butanol } \\
(\mathrm{Bu})\end{array}$ \\
\hline Density at $15^{\circ} \mathrm{C}, \mathrm{kg} / \mathrm{m}^{3}$ & EN ISO 12185:1999 & 884.7 & 810 \\
\hline $\begin{array}{l}\text { Kinematic viscosity, } \mathrm{mm}^{2} / \mathrm{s} \text { at } 40 \\
{ }^{\circ} \mathrm{C}\end{array}$ & EN ISO 3104+AC:2000 & 4.8 & 2.63 \\
\hline $\begin{array}{l}\text { Lubricity (HFRR), wear scar } \\
\text { diameter (wsd 1.4) at } 60{ }^{0} \mathrm{C}, \mu \mathrm{m}\end{array}$ & EN ISO 12156-1 & 205 & 591 \\
\hline Flash point, open cup, ${ }^{\circ} \mathrm{C}$ & EN ISO 2719:2000 & 168 & 35 \\
\hline Initial / final boiling points, ${ }^{0} \mathrm{C}$ & EN ISO 3405:2011 & $346 / 366$ & 117.7 \\
\hline Auto-ignition temperature ${ }^{0} \mathrm{C}$ & - & $\sim 342$ & $\sim 343$ \\
\hline Cetane number & EN ISO 5165:1999 & 53.4 & 25 \\
\hline Oxygen content, max wt\% & - & 10.9 & 21.62 \\
\hline Carbon-to-hydrogen ratio $(\mathrm{C} / \mathrm{H})$ & - & 6.49 & 4.8 \\
\hline Stoichiometric air/fuel ratio, $\mathrm{kg} / \mathrm{kg}$ & - & 12.62 & 11.12 \\
\hline Net heating value, $\mathrm{MJ} / \mathrm{kg}$ & EN ISO 8217:2012 & 37.23 & 33.08 \\
\hline
\end{tabular}

The experimental examinations performed in the engine-test laboratory at Power and Transport Machinery Engineering Institute of Vytautas Magnus University - Agricultural Academy. The technical characteristics in more details are listed in Table 2.

Table 2. Engine FL 511 specifications

\begin{tabular}{|l|l|}
\hline Type & Deutz FL 511 \\
\hline Number of strokes & 4 stroke \\
\hline Number of cylinders & Single-cylinder \\
\hline Bore, $\mathrm{mm}$ & 100 \\
\hline Stroke, $\mathrm{mm}$ & 105 \\
\hline Displacement volume, $\mathrm{cm}^{3}$ & 825 \\
\hline Compression ratio & 17 \\
\hline Injection timing advance in CADs before TDC & $24^{\circ}$ \\
\hline Maximum power (at $3000 \mathrm{rpm}), \mathrm{kW}$ & $12.8 \pm 5 \%$ \\
\hline Injection pressure, bar & $175 \pm 5 \mathrm{bar}$ \\
\hline Specific fuel consumption, $\mathrm{g} / \mathrm{kW} \cdot \mathrm{h}$ & $255 \pm 5 \%$ \\
\hline Rated speed, $\mathrm{rpm}$ & 3000 \\
\hline Engine weight, $\mathrm{kg} 135$ & 135 \\
\hline
\end{tabular}

Torque of an engine was measured with a magnetic powder brake dynamometer PT40M $(0-60 \mathrm{~N} \cdot \mathrm{m})$ with a definition rate of $\pm 0.5 \mathrm{~N} \cdot \mathrm{m}$ and rotation speed with a mechanical tachometer (150-3000 rpm) with an accuracy of $\pm 0.5 \%$ of the measured value. The air mass consumption was measured with a turbine type gas meter CGT-02 $\left(10-100 \mathrm{~m}^{3} / \mathrm{h}\right)$ with an accuracy of $\pm 1 \%$ of the measured value, and fuel mass consumption by using electronic scale SK-1000 with an accuracy of $\pm 0.5 \%$.

Emissions of nitric oxide (NO), nitrogen dioxide $\left(\mathrm{NO}_{2}\right)$, carbon monoxide $(\mathrm{CO})$ in parts per million (ppm) and carbon dioxide $\left(\mathrm{CO}_{2}\right)$ in vol\% were measured with electrochemical cells installed in Testo $350 \mathrm{XL}$ flue gas analyser. Total $\mathrm{NO}_{\mathrm{x}}$ emissions were determined as a sum of both $\mathrm{NO}$ and $\mathrm{NO}_{2}$ pollutants with an accuracy of $\pm 5 \mathrm{ppm}$. Exhaust smoke was measured with a Bosch RTT 110 opacity meter with an accuracy of $\pm 0.1 \%$ in a scale range of $0-100 \%$. To improve reliability of the measured data the tests have been repeated no less than three times.

\section{RESULTS AND DISCUSSION}

The summarised effect of the widely differing chemical and physical properties and net heating values of the biofuels studied along with the changes in the auto-ignition and combustion peculiarities have 
influence on the fuel mas burned over an hour $(\mathrm{kg} / \mathrm{h})$ and the fuel mass consumed per unit of effective power $(\mathrm{g} / \mathrm{kWh})$ developed by an engine. As can be seen in graphs of Figs. 1a and $\mathrm{b}$, both the mass of the fuel consumed over an hour $\left(\mathrm{B}_{\mathrm{d}}\right)$ and the brake specific fuel consumption (bsfc) for neat biodiesel are lower over the whole load-range tested compared to the engine running on less calorific biodiesel-n-butanol blends. The noted differences in the bsfc values are mainly observable when running at a light load, low pressure and temperature in the cylinder because the auto-ignition delay extends due to the presence of more volatile nbutanol with both the cooling effect and the reduced $\mathrm{CN}$ rating that may negatively affect the combustion of the blends. For the above reasons and slightly lower calorific value, the brake specific fuel consumptions for the respective blends BBu5-BBu15 are up to $1.08 \%-14.80 \%$ higher than, $798.7 \mathrm{~g} / \mathrm{kWh}$, neat biodiesel suggests for light-load operation.
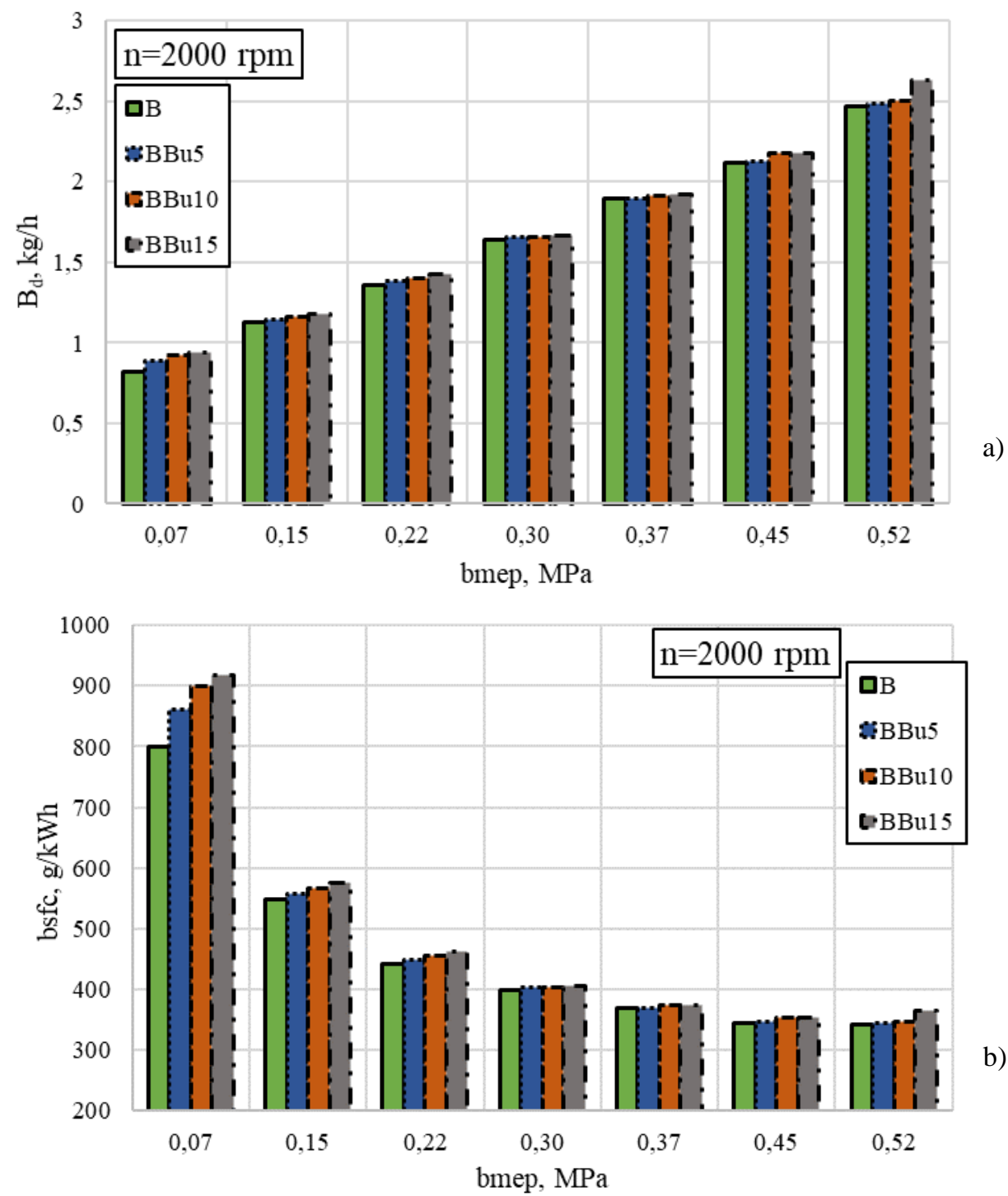

Fig. 1. The fuel mass consumption per hour $\left(B_{d}\right)$ and brake specific fuel consumption (bsfc) as a function of engine load when running at maximum torque speed of $2000 \mathrm{rpm}$.

As soon as the temperature inside the cylinder increases with engine load increased to about $0.30 \mathrm{MPa}$, the differences in brake specific fuel consumptions are also less observable and the bsfe values for the respective blends BBu5-BBu15 sustain at about $1.15 \%-1.85 \%$ higher levels than, $398.4 \mathrm{~g} / \mathrm{kWh}$, the neat biodiesel consumes at considered test conditions. As could be reasonably expected, the bsfc values remain relatively up to $0.69 \%-6.57 \%$ higher for n-butanol oxygenated biodiesel blends BBu5 - BBu15 when running at a full (100\%) load as well than, $343.1 \mathrm{~g} / \mathrm{kWh}$, neat biodiesel suggests for the same loading conditions at maximum torque speed of $2000 \mathrm{rpm}$. The relatively higher brake specific fuel consumption of binary biofuels BBu5 - BBu15 can be mainly attributed to the lower net heating value of plenty oxygenated biodiesel-n-butanol blends. 
The biggest relative decrease in the brake thermal efficiency of an engine reasonably obtained when running with neat biodiesel and biofuel blends tested under the low loads and thus not as high as would be needed for fuel-efficient operation the temperature inside the cylinder. As shown in Fig. 2a, an engine develops the lowest brake thermal efficiency value of 0.107 (11.6\% lower) when running with the most $n$ butanol oxygenated blend $\mathrm{BBu} 15$ and the maximum one of 0.121 with neat biodiesel at the lowest $0.07 \mathrm{MPa}$ load. The obtained energy conversion efficiencies of biofuel blends match well with obvious differences in the cetane number, negative changing trends in the combustion noise, engine performance stability and the respective bsfc values (Fig. 2b) measured when running with blend BBu15 at the lowest load. The brake thermal efficiency gradually increased with engine load and the temperature inside the cylinder to reach for neat biodiesel and slightly n-butanol oxygenated blend BBu5 the same maximum value of 0.282 remaining $1.4 \%$ and $4.3 \%$ lower engine efficiencies, 0.281 and 0.270 , for the respective $n$-butanol blends $\mathrm{BBu} 10$ and BBu15 when running under full (100\%) load conditions.
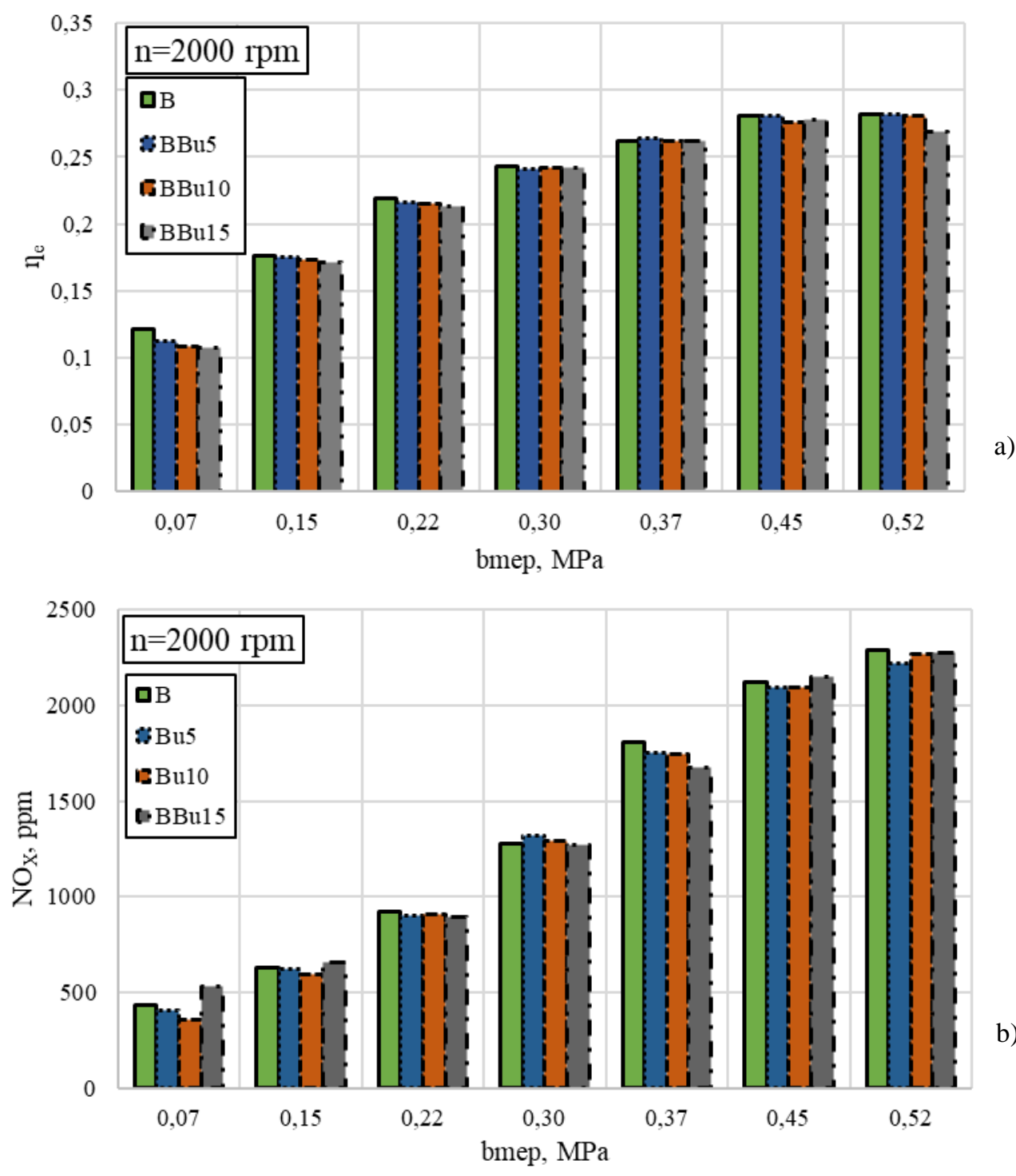

Fig. 2. The brake thermal efficiency $\left(\eta_{\mathrm{e}}\right)$ and total nitrogen oxide $\left(\mathrm{NO}_{\mathrm{x}}\right)$ emissions as a function of engine load when running at maximum torque speed of $2000 \mathrm{rpm}$.

High evaporative cooling effect and low calorific value of n-butanol can be realised in practise bearing in mind that the production of $\mathrm{NO}_{\mathrm{x}}$ relies primary on the temperature inside the cylinder, local oxygen concentration, the residence time limited by the combustion reactions, and relative (overall) air/fuel ratio [10], but less depends on the availability of the local oxygen [11]. The total $\mathrm{NO}_{\mathrm{x}}$ emissions sustain at a reasonable levels when running at the lowest $0.07 \mathrm{MPa}$ load varying within the narrow range from $397 \mathrm{ppm}$ for neat biodiesel to $476 \mathrm{ppm}$ for the biggest mass content of n-butanol containing biofuel $\mathrm{BBu} 15$. The relatively $19.9 \%$ higher $\mathrm{NO}_{\mathrm{x}}$ emissions emanating from the combustion reaction of the most n-butanol 
involving blend $\mathrm{BBu} 15$ can be reasonably attributed to the fact that the temperature inside the cylinder is too low to keep smooth operation of an engine on plenty n-butanol oxygenated biodiesel blend at the lowest load. Therefore, the increased combustion instability accompanied by the high noise levels and the incylinder pressure oscillations contributed to the production of more $\mathrm{NO}_{\mathrm{x}}$ emissions in this particular low-load conditions (Fig. 2b).

The production of $\mathrm{NO}_{\mathrm{x}}$ emissions gradually increases with engine load and thus the temperature inside the cylinder reaching the lowest value, $1121 \mathrm{ppm}$, for neat biodiesel and the biggest one, $1219 \mathrm{ppm},(8.7 \%$ higher) for the combustion of blend BBu5 when running at about medium (50\% of full) load. As could be expected, the $\mathrm{NO}_{\mathrm{x}}$ emissions increase to the maximum value of $2132 \mathrm{ppm}$ for neat biodiesel sustaining at relatively $3.0 \%, 0.9 \%$ and $0.5 \%$ lower levels for the respective biodiesel-n-butanol blends BBu5, BBu10 and $\mathrm{BBu} 15$ when running under the full $(100 \%)$ load conditions. It is challenging to define the reasons, but in fact, the obtained result provides excellent finding revealing that the higher $n$-butanol mass content ( $\mathrm{v} / \mathrm{v} \%)$ is added to biodiesel blend, the lower actually its contribution to the reduction intensity of maximum $\mathrm{NO}_{\mathrm{x}}$ emissions can be expected. The potential answer to this intriguing question lies perhaps beyond the fact that the $\mathrm{NO}_{\mathrm{x}}$ emissions emerge mainly during the first kinetic combustion phase under the high temperatures above $2000 \mathrm{~K}$ where a key role in the $\mathrm{NO}_{\mathrm{x}}$ production plays the air-borne oxygen.

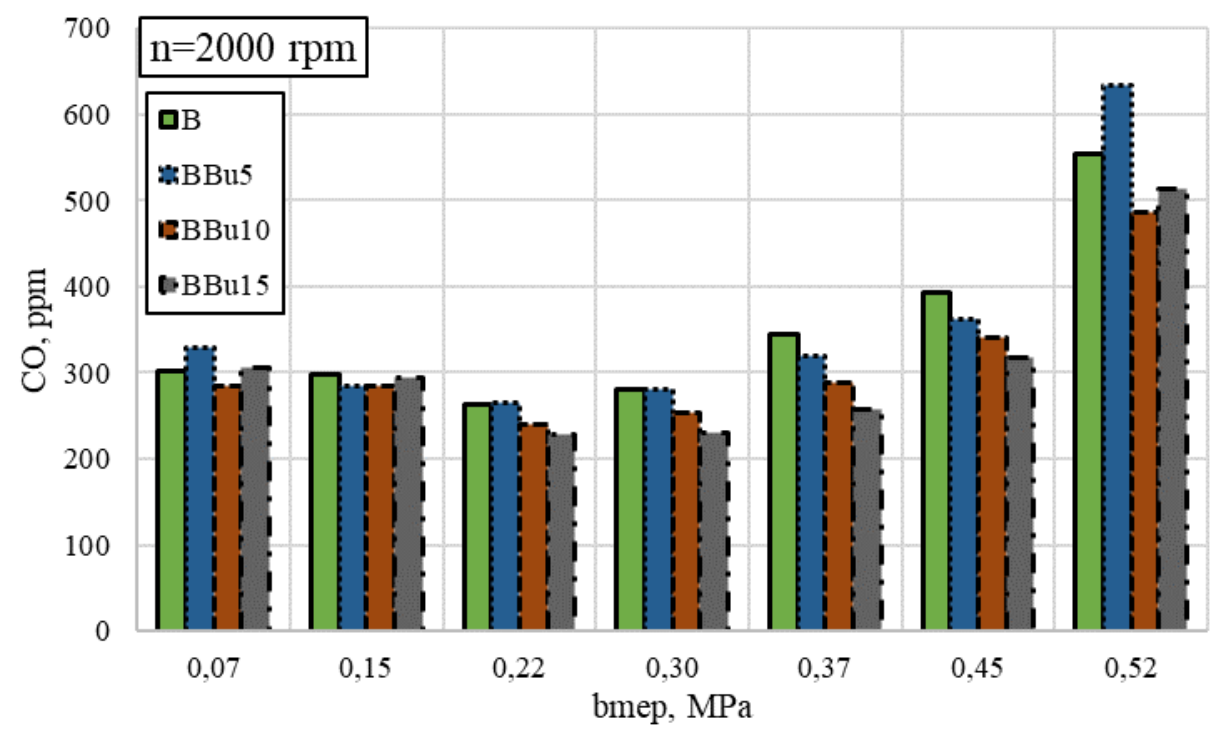

a)

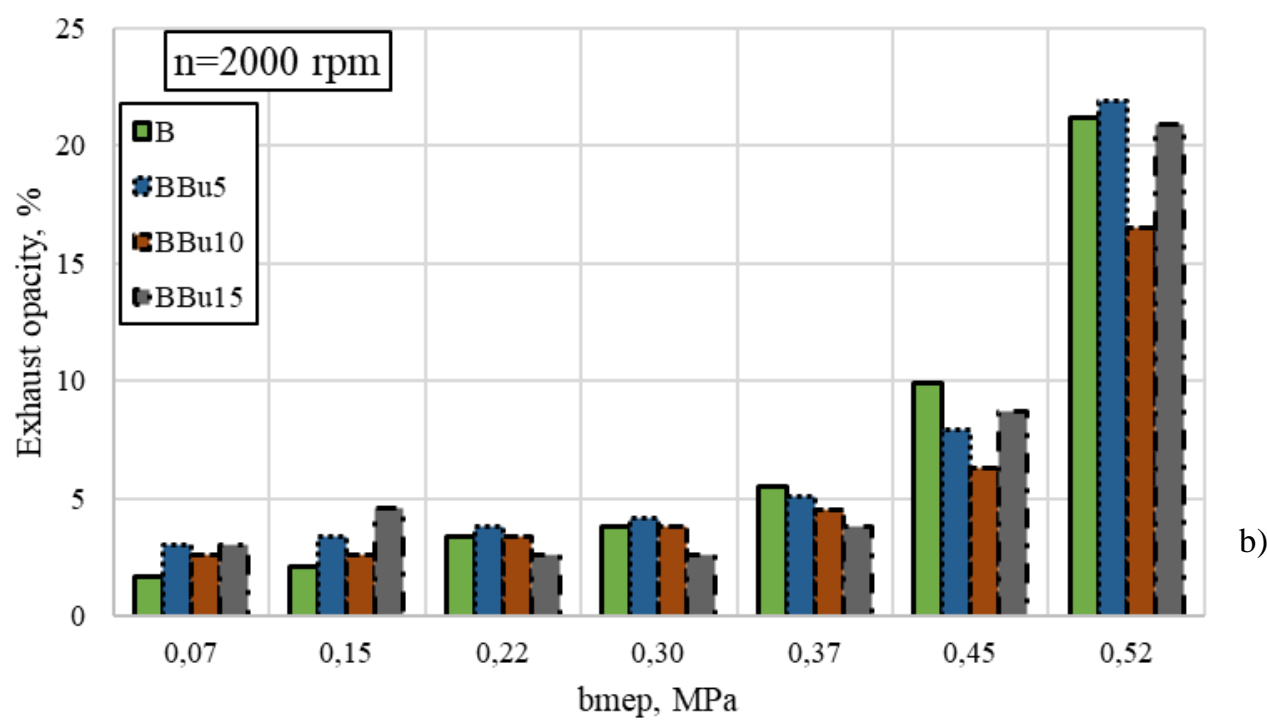

Fig. 3. Dependencies of carbon monoxide (CO) emissions (a) and smoke opacity of the exhaust (b) on engine load when running at maximum torque speed of $2000 \mathrm{rpm}$.

While the biofuel-bound oxygen takes only a second-rate role coming into effect too late in the expansion stroke during the diffusion-controlled combustion phase and thus with a little help to contribute to the NOx production. For this reason, the effect of the fuel-bound oxygen on the NOx emissions changing trends can be ambiguous enough, hardly predictable and dependable on the feedstock materials, origin and 
production technology of the biofuel as well as on the combustion chamber type and the test conditions of an engine, particularly on the relative (overall) air/fuel ratio.

In contrast to ambiguous the $\mathrm{NO}_{\mathrm{x}}$ emissions behaviour, the positive effect of the lower $\mathrm{C} / \mathrm{H}$ atoms ratio strongly supported by both the absence of polycyclic aromatic hydrocarbons in the composition of biodieseln-butanol biofuels and the increased n-butanol-oxygen mass (wt, \%) content, significantly contributes to enhance combustion and thus drastically reduce $\mathrm{CO}, \mathrm{CO}_{2}$ emissions and visible smoke of the exhaust. At the beginning of engine loading, the $\mathrm{CO}$ emissions relatively decrease to be 5.6\% lower mainly for the blend's $\mathrm{BBu} 10$ case, while unstable combustion of the respective blends $\mathrm{BBu} 5$ and $\mathrm{BBu} 15$ produce $\mathrm{CO}$ emissions 9.3\% and $1.3 \%$ higher than neat biodiesel suggests, $302 \mathrm{ppm}$, when running at the lowest $0.07 \mathrm{MPa}$ load (Fig. 3a).

As soon as the engine load increases to about medium (50\% of full) value and the temperature inside the cylinder boosts up, both most n-butanol oxygenated blends BBu10 and BBu15 reveal themselves as having strong potentials to drastically reduce the carbon monoxide (CO) emissions by $8.9 \%$ and $17.5 \%$, respectively. The noted positive $\mathrm{CO}$ emissions changing trends with using the most $\mathrm{n}$-butanol oxygenated biodiesel blends BBu10 and BBu15 actually remain in value after transition to full (100\%) load operation as well. The enhanced combustion of the respective blends BBu10 and BBu15 produces the $\mathrm{CO}$ emissions $12.4 \%$ and $7.4 \%$ lower than, $555 \mathrm{ppm}$, the neat biodiesel emits under full $(100 \%)$ load operation. Only the combustion of the blend $\mathrm{BBu} 5$ produces the $\mathrm{CO}$ emissions relatively $14.1 \%$ higher, most likely, due to an inevitable pay off required to compensate for the merits experienced with having the relatively lowest $\mathrm{NO}_{\mathrm{x}}$ production when running under full (100\%) load at maximum torque speed of $2000 \mathrm{rpm}$ (Fig. 2b).

Smoke opacity characteristics proceed at the low levels compiling only $3.4 \%, 2.6 \%$ and $4.6 \%$, however transparency of the exhausts for the respective n-butanol oxygenated blends BBu5, BBu10 and BBu15 is relatively $61.9 \%, 23.8 \%$ and 2.2 times not as good as that, $2.1 \%$, neat biodiesel produces when running at $0.15 \mathrm{MPa}$ load and maximum torque speed of $2000 \mathrm{rpm}$ (Fig. 3b). This phenomenon of smoke is the evidential fact that biofuel vapours do not burn completely at the low load, so they additionally affect transparency of the exhaust if or when the temperature inside the cylinder is not as high as would be needed to support efficient combustion and take under control the cyclic variability of operational parameters. As could be reasonably expected, the lowest smoke opacity produces the combustion of most n-butanol oxygenated blend $\mathrm{BBu} 15$ that is $31.6 \%$ lower than, 3.8\%, neat biodiesel suggests when running at about medium (50\% of full) load. While less n-butanol oxygenated biodiesel blend BBu10 took real advantage to enhance combustion and reduce smoke opacity by $20.9 \%$ than that, $21.2 \%$, neat biodiesel produces under full $(100 \%)$ load at maximum torque speed of $2000 \mathrm{rpm}$.

\section{CONCLUSIONS}

1. The brake specific consumption of biodiesel-n-butanol blends BBu5-BBu15 is $1.08 \%-14.80 \%, 1.15 \%$ $1.85 \%$ and $0.69 \%-6.57 \%$ higher than the respective bsfc values, 798.7, 398.4 and $343.1 \mathrm{~g} / \mathrm{kWh}$, neat biodiesel suggests for studied loading conditions of $0.07,0.30$ and $0.52 \mathrm{MPa}$ at maximum torque speed of $2000 \mathrm{rpm}$. The main reason of having relatively higher the bsfc for oxygenated blends is much lower net heating value of the added n-butanol.

2. The brake thermal efficiency suffered relative decrease to 0.107 (11.6\% lower) when running with the most n-butanol oxygenated blend BBu15 at the lowest load of $0.07 \mathrm{MPa}$. However, thermal efficiency increased to reach the same maximum of 0.282 for neat biodiesel and blend BBu5 remaining, 0.281 and 0.270 , that is relatively $1.4 \%$ and $4.3 \%$ lower for more $\mathrm{n}$-butanol containing blends $\mathrm{BBu} 10$ and $\mathrm{BBu} 15$ when running under full (100\%) load conditions.

3. The highest total $\mathrm{NO}_{\mathrm{x}}$ emissions, $2132 \mathrm{ppm}$, produces the combustion of neat biodiesel, while the positive effect of n-butanol oxygenated biodiesel blends on the $\mathrm{NO}_{\mathrm{x}}$ suppression is not as huge as could be expected. This is because the $\mathrm{NO}_{\mathrm{x}}$ reduction intensity decreases $3.0 \%, 0.9 \%$ and $0.5 \%$ when running an engine with n-butanol oxygenated biodiesel blends BBu5, BBu10 and BBu15 under the full (100\%) load at maximum torque speed of $2000 \mathrm{rpm}$.

4. Both most n-butanol oxygenated biodiesel blends $\mathrm{BBu} 10$ and $\mathrm{BBu} 15$ revealed themselves as having strong potentials to drastically reduce the carbon monoxide (CO) emissions by $8.9 \%$ and $17.5 \%$, respectively, when running at about medium (50\% of full) load. The enhanced combustion of the carbon-limited, plenty oxygenated blends $\mathrm{BBu} 10$ and BBu15 emitted the $\mathrm{CO}$ emissions $12.4 \%$ and $7.4 \%$ less than, $555 \mathrm{ppm}$, the neat biodiesel produces for full load conditions as well.

5. The lowest smoke opacity produces the combustion of plenty n-butanol oxygenated biodiesel blend $\mathrm{BBu} 15$, which is $31.6 \%$ lower than, $3.8 \%$, neat biodiesel suggests running at about medium $(50 \%$ of full) loading conditions. While less n-butanol oxygenated biodiesel blend BBu10 took advantage the 
enhanced combustion of which reduces smoke opacity by $20.9 \%$ than, $21.2 \%$, neat biodiesel produces under full (100\%) load at maximum torque speed of $2000 \mathrm{rpm}$.

Taking into account the above merits, renewable binary biodiesel-n-butanol blends are suitable for diesel engine powering to replace fossil-origin diesel fuels, reduce the climate change and safe the untouched nature for future generations. The Ball On-Cylinder or BOCLE tests showed that biodiesel derived from rapeseed oil has superior lubricity compared to low sulphur diesel fuel [12] and thus the wear-sensitive fuel system designs such as plunger-barrel and the needle-valve-barrel units are able to tolerate up to 15 vol\% nbutanol additions to biodiesel.

\section{REFERENCES}

1. Directive 2009/28/EC of the European Parliament and of the Council of 23 April 2009 on the promotion of the use of energy from renewable sources and amending and subsequently repealing Directives 2001/77/EC and 2003/30/EC. Available at: eur-lex.europa.eu.

2. Giakoumis E., Rakopoulos C.D., Dimaratos A.M., Rakopoulos D.C. Exhaust emissions with ethanol or nbutanol diesel fuel blends during transient operation: A review. Renewable and Sustainable Energy Reviews, 2013, Vol. 17, Issue 1 - January, p. 170-190. ISSN 2229-5518.

3. Rakopoulos D.C., Rakopoulos C.D., Giakoumis E.G., Komninos N.P., Kosmadakis G.M., Papagiannakis R.G. Comparative evaluation of ethanol, n-butanol, and diethyl ether effects as biofuel supplements on combustion characteristics, cyclic variations, and emissions balance in light-duty diesel engine. Journal of Energy Engineering, 2017, Vol. 143, Issue 2 - April 2017, p. 04016044-1-04016044-8.

4. Labeckas G., Slavinskas S., Rudnicki J., Zadrąg R. The effect of oxygenated diesel-n-butanol fuel blends on combustion, performance, and exhaust emissions of a turbocharged CRDI diesel engine. Polish Maritime Research, 2018, Vol. 25, No 1 (97), pp. 108-120, doi: 10.2478/pomr-2018-0013.

5. Sukjit E., Herreros J.M., Dearn K.D., Tsolakis A., Theinnoi K. Effect of hydrogen on butanol-biodiesel blends in compression ignition engines. International Journal of Hydrogen Energy, 2013-02-06, Vol. 38, Issue 3, p. 1624-1635. doi: 10.1016/j.ijhydene.2012.11.061.

6. Wei L., Cheung C.S., Ning Z. Effects of biodiesel-ethanol and biodiesel-butanol blends on the combustion, performance and emissions of a diesel engine. Energy, 2018-07-15, Vol. 155, Issue 3, p. 957-970, doi.org/10.1016/j.energy.2018.05.049.

7. Zöldy M. Fuel Properties of Butanol-Hydrogenated Vegetable Oil Blends as a Diesel Extender Option for Internal Combustion Engines. Periodica Polytechnica Chemical Engineering, 2020, Vol. 64, Issue 2, p. 205 212. https://doi.org/10.3311/PPch.14153.

8. Labeckas G., Slavinskas S., Kanapkienè I. Study of the effects of biofuel-oxygen of various origins on a CRDI diesel engine combustion and emissions. Energies, Based : MDPI AG, 2019, Vol. 12, Issue 7, p. 1-49. https://hdl.handle.net/20.500.12259/61885.

9. Rakopoulos D.C., Rakopoulos C.D., Giakoumis E.G. Impact of properties of vegetable oil, bio-diesel, ethanol and n-butanol on the combustion and emissions of turbocharged HDDI diesel engine operating under steady and transient conditions. Fuel, 2015, Vol. 156, Issue 9 - September, p. 1-19, doi: 10.1016/j.fuel.2015.04.021.

10. Shahir S.A., Masjuki H.H., Kalam M.A., Imran A., Ashraful A.M. Performance and emission assessment of diesel-biodiesel-ethanol/bioethanol blend as a fuel in diesel engines: A review. Renewable and Sustainable Energy Reviews, 2015, Vol. 48, Issue 8, p. 62-78, doi:10.1016/j.rser.2015.03.049.

11. Papagiannakis R.G., Rakopoulos D.C., Rakopoulos C.D. Evaluation of the air-oxygen enrichment effects on combustion and emissions of natural gas/diesel dual-fuel engines at various loads and pilot fuel quantities. Energies, 2018, Vol. 11, Issue 11, 3028, p. 1-23, doi:10.3390/en11113028.

12. Graboski M.S., McCormick R.L. Combustion of Fat and Vegetable Oil Derived Fuels in Diesel Engines. Progress in Energy and Combustion. Scientific. Vol. 24 1998, p. 125-164, Elsevier Science Ltd.

ЛАБЕЦКАС Гвидонас, доктор технических наук, профессор института инженерии силовых и транспортных машин, университет им. Витаутаса Магнуса, e-mail: gvidonas.labeckas@ vdu.lt;

СЛАВИНСКАС Стасис, доктор технических наук, профессор, заведующий института инженерии силовых и транспортных машин, университет им. Витаутаса Магнуса, e-mail: stasys.slavinskas@vdu.lt;

МИЦКЯВИЧЮС Томас, доктор технических наук, е-таil: преподаватель института инженерии силовых и транспортных машин, университет им. Витаутаса Магнуса t.mickevicius@yahoo.com; 
Gvidonas LABECKAS, Ph.D. in Engineering, Professor of Power and Transport Machinery Engineering Institute, Vytautas Magnus University, e-mail: gvidonas.labeckas@vdu.lt;

Stasys SLAVINSKAS, Ph.D. in Engineering, Professor, Head of Power and Transport Machinery Engineering Institute, Vytautas Magnus University, e-mail: stasys.slavinskas@vdu.lt;

Tomas MACKEVIČIUS, Ph.D. in Engineering, lecturer of Power and Transport Machinery Engineering Institute, Vytautas Magnus University, e-mail: gvidonas.labeckas@asu.lt;e-mail: t.mickevicius@yahoo.com

DOI: https://doi.org/10.36910/automash.v1i14.342 